\title{
Kondisi megabentos di perairan Kabupaten Sumba Timur, Provinsi Nusa Tenggara Timur
}

\section{(Megabentos condition in East Sumba Regency Waters, Province of East Nusa Tenggara)}

\author{
Hendrik A.W. Cappenberg ${ }^{1}$ dan Nebuchadnezzar Akbar ${ }^{2}$ \\ ${ }^{1}$ Pusat Penelitian Oseanografi - LIPI, Jl. Pasir Putih I Ancol Timur, Jakarta 14430 \\ ${ }^{2}$ Fakultas Perikanan dan Kelautan. Universitas Khairun. Ternate \\ e-mail: hendrik_awc@yahoo.com
}

Diterima: 17 September 2020; Disetujui: 30 November 2020

\begin{abstract}
ABSTRAK
Terumbu karang merupakan habitat penting bagi berbagai biota yang hidup berasosiasi di dalamnya. Beberapa jenis megabentos mendiami terumbu karang memiliki nilai ekologis dan ekonomis penting, sehingga dapat dijadikan sebagai indikator untuk menilai kesehatan terumbu. Penelitian megabentos di perairan Pulau Sumba, Kabupaten Sumba Timur dilakukan Oktober 2018. Tujuan penelitian untuk mengetahui kondisi megabentos di perairan Sumba Timur. Pengambilan sample menggunakan metode Benthos Belt Transect yang dimodifikasi dari Belt Transect Method. Hasil analisis menunjukkan nilai kepadatan individu di setiap stasiun berkisar dari 0,14-0,74 individuals $/ \mathrm{m}^{2}$, dengan Diadema spp. memiliki kepadatan tertinggi (2,62 individu/ $\left.\mathrm{m}^{2}\right)$, diikuti Drupella spp. (1,06 individu/ $\left.\mathrm{m}^{2}\right)$, kemudian Panulirus spp. dan Linckia laevigata memiliki kepadatan terendah $\left(0,01\right.$ individu $\left./ \mathrm{m}^{2}\right)$. Nilai indeks keanekaragaman $\left(\mathrm{H}^{\prime}\right)$ berkisar antara $0,45-1,18$, indeks kemerataan jenis $(\mathrm{J}$ ') berkisar antara 0,32-0,82 dan indeks dominasi (D) berkisar antara 0,35-0,81. Secara umum, kondisi megabentos diperairan Kabupaten Sumba Timur berada dalam kategori rendah hingga sedang.
\end{abstract}

Kata kunci: Kondisi, megabentos, terumbu karang, Sumba Timur

\section{ABSTRACT}

The coral reef is important habitats for various biota that live in association in this ecosystem. Several species of macrobenthos that inhabit coral reefs have important ecological and economic values, so they can be used as indicators to assess reef health. Research on macrobenthos fauna in Sumba Island waters, East Sumba Regency, was carried out in October 2018. The purpose of this study was to determine the condition of several macrobenthos in East Sumba waters. Data were collected using the modified Belt Transect Method, namely Benthos Belt Transek Method. The analysis shows that the abundance of macrobenthos ranged from 0.14 to 0.74 individuals $/ \mathrm{m}^{2}$. Diadema spp. had the highest abundance (2.62 individuals $/ \mathrm{m}^{2}$ ), followed by Drupella cornus (1,06 individuals $/ \mathrm{m}^{2}$ ) and the lowest was Panulirus spp. (crustacea class) and Linkia laevigata (0.01 individuals $\left./ \mathrm{m}^{2}\right)$. Species diversity index ( $\left.H^{\prime \prime}\right)$ ranged from 1.09 to 1.29 , evenness index $(J$ ') ranged from 0.80 to 0.92 and species dominance index (D) was between 0.06 and 0.13. In general, the conditions for megabenthos in the waters of East Sumba Regency are in the low to medium category.

Keywords: Coral reef, condition, East Sumba, macrobenthos 
Citasi : Cappenberg H AW, Akbar N. 2020.Kondisi megabentos di perairan Kabupaten Sumba Timur, Provinsi Nusa Tenggara Timur, 3 (2) : 130 - 146

\section{Pendahuluan}

Secara geografis Pulau Sumba terletak di barat daya Propinsi Nusa Tenggara Timur tepatnya berjarak sekitar $96 \mathrm{~km}$ di sebelah selatan Pulau Flores, $295 \mathrm{~km}$ di sebelah barat daya Pulau Timor dan $1.125 \mathrm{~km}$ di sebelah barat laut Darwin Australia, dan secara administratif, termasuk kedalam wilayah Provinsi Nusa Tenggara Timur. Pulau Sumba sendiri memiliki empat kabupaten, seperti Kabupaten Sumba Barat, Kabupaten Sumba Barat Daya, Kabupaten Sumba Tengah, dan Kabupaten Sumba Timur. Kota terbesarnya adalah Waingapu, yang merupakan ibukota Kabupaten Sumba Timur. Kota tersebut juga terdapat bandar udara dan pelabuhan laut yang menghubungkan Pulau Sumba dengan pulau-pulau lainnya di Indonesia seperti Pulau Sumbawa, Pulau Flores, dan Pulau Timor. Kawasan perairan pantai Kabupaten Sumba Timur memiliki keragaman ekosistem yang cukup lengkap seperti mangrove, lamun dan terumbu karang. Ketiga ekosistem ini sering ditemukan secara bersamaan pada hampir setiap stasiun penelitian, dengan luas yang cukup bervariasi. Adanya ketiga ekosistem tersebut secara fisik dapat melindung pantai dari abrasi serta menjadi habitat dari berbagi organisme. Namun tingginya aktivitas penduduk setempat dalam memanfaatkan sumberdaya perikanan pesisir pantai dengan tidak rama lingkungan dapat merusak ekosistem tersebut, seperti penggunaan bom dan potas dalam menangkap ikan.

Terumbu karang merupakan ekosistem perairan pantai yang kompleks dan kaya akan keanekaragaman hayati. Semakin baik ekosistem terumbu maka peluang untuk mendapatkan biota yang hidup berasosiasi pada ekosistem tersebut semakin beragam dan melimpah jumlah individunya. Banyak kelompok megabentos seperti polikaeta, krustase, ekinodermata dan moluska menempati ekosistem ini. Beberapa jenis biota diantara kelompok tersebut dapat menjadi bioindikator untuk menilai kondisi ekosistem perairan karena cara hidupnya yang menetap atau bergerak sangat lambat. Kelompok fauna megabentos ini tidak semua dapat terlihat dengan jelas, kecuali beberapa jenis krustase, ekinodermata dan moluska berukuran besar (Nybakken, 1992). Terumbu karang memiliki banyak manfaat, namun rentan terhadap perubahan lingkungan, dimana ukurannya dapat bertambah atau berkurang sebagai akibat adanya interaksi yang kompleks antar berbagai kekuatan biologis dan fisik. Tekanan atau gangguang tersebut dapat berdampak langsung pada kehidupan terumbu karang maupun keragaman fauna megabentos yang hidupnya selalu menempel (sessil) pada substrat.

Kondisi terumbu karang secara umum semakin terancam oleh perubahan iklim global melalui kenaikan suhu laut, pengasaman laut, pemutihan karang, dan peningkatan frekuensi dan tingkat keparahan kejadian badai (Hoegh-Guldenberg et al, 2007; Ham, 2018; Hughes et al, 2018). Pemicu stres dan gangguan lain yang mengancam keberadaan terumbu karang juga terjadi seperti kehadiran bintang laut pemakan karang, tekanan penangkapan ikan, dan polusi yang mengancam melalui penurunan kompleksitas permukaan terumbu, hilangnya tutupan karang hidup, yang didominasi makroalga (Hoegh-Guldenberg et al, 2007; Fabricius et al, 2013; Hughes et $a l, 2018)$. Perubahan habitat terumbu karang dapat menimbulkan konsekuensi serius bagi jenis yang bergantung pada substrat, termasuk mengubah pola distribusi dan interaksi jenis, yang seringkali menyebabkan penurunan kelimpahan populasi (Przeslawski et al, 2008; Bozec et al, 2015; Hughes et al, 2018). 
Kehadiran fauna megabentos pada perairan terumbu karang dipengaruhi oleh karakter substrat. Semakin beragam tipe substrat (heterogen), semakin besar peluang megabentos ditemukan hidup pada ekosistem tersebut. Arthur (1972) menyatakan bahwa sebaran dan kompleksitas habitat berpengaruh terhadap kelimpahan dan keanekaragaman jenis. Kelompok megabentos merupakan salah satu bagian dalam rantai makanan pada ekosistem perairan yang dapat mempengaruhi keberadaan biota lain, dan sebagai makanan ikan demersal dan mamalia laut (Kronck and Reiss, 2010; Tabatabaien and Amiri, 2011; Sahidin dan Wardiatno, 2016).

Informasi dan data fauna megabentos yang memiliki nilai ekologis dan ekonomis penting serta dapat menjadi indikator kesehatan terumbu karang di perairan Kabupaten Sumba Timur belum perna dilaporkan sebelumnya. Penelitian ini bertujuan untuk mengetahui kondisi fauna megabentos pada perairan tersebut. Hasil penelitian diharapkan dapat melengkapi dan menambahkan informasi mengenai fauna meganbentos dari perairan Kabupaten Sumba Timur, dan dapat menjadi pertimbangan dalam pemanfaatn dan pengelolahan wilayah pesisir secara lestari.

\section{Metode penelitian \\ II.1. Lokasi penelitian}

Penelitian fauna megabentos Oktober 2018 pada 10 stasiun yang tersebar dari sebelah timur hingga selatan pesisir pantai Kabupaten Sumba Timur (Gambar 1 dan Tabel 1)

\section{II.2. Pengambilan data}

Pengambilan contoh fauna megabentos dilakukan pada kedalaman 6-10 m dengan menggunakan metode Benthos Belt Transect (BBT) (Giyanto et al, 2014). Peralatan yang digunakan adalah alat selam (SCUBA), alat tulis bawah air dan roll meter. Transek sepanjang 70 meter dibuat sejajar garis pantai (tubir), dengan jarak pengamatan 1 meter kiri dan kanan (lebar daerah pengamatan $2 \mathrm{~m}$ ), sehingga luas daerah pengamatan setiap titik stasiun adalah $140 \mathrm{~m}^{2}(2 \times 70 \mathrm{~m})$.

Kelompok megabentos yang dicatat jenis dan jumlah individunya sepanjang garis transek terdiri dari Acanthaster planci (binatang bulu seribu), Diadema spp. (bulu babi hitam), Drupella sp. (jenis gastropodaatau keong yang hidup di sela-sela karang terutama karang bercabang), Holothurian (teripang), Panulirus spp. (lobster/udang karang atau udang barong), Tridacna spp. (kima) dan Trochus spp. Fauna megabentos tersebut dapat digunakan sebagai indikator untuk menilai tingkat kesehatan terumbu karang (Manuputty et al, 2006). Identifikasi fauna megabentos dilakukan berdasarkan beberapa referensi, seperti Abbott and Dance (1990); Clark and Rowe (1971); Dance (1976); Dharma (1992); Poutiers (1998); Dharma (2005) dan Wilson (1993). 


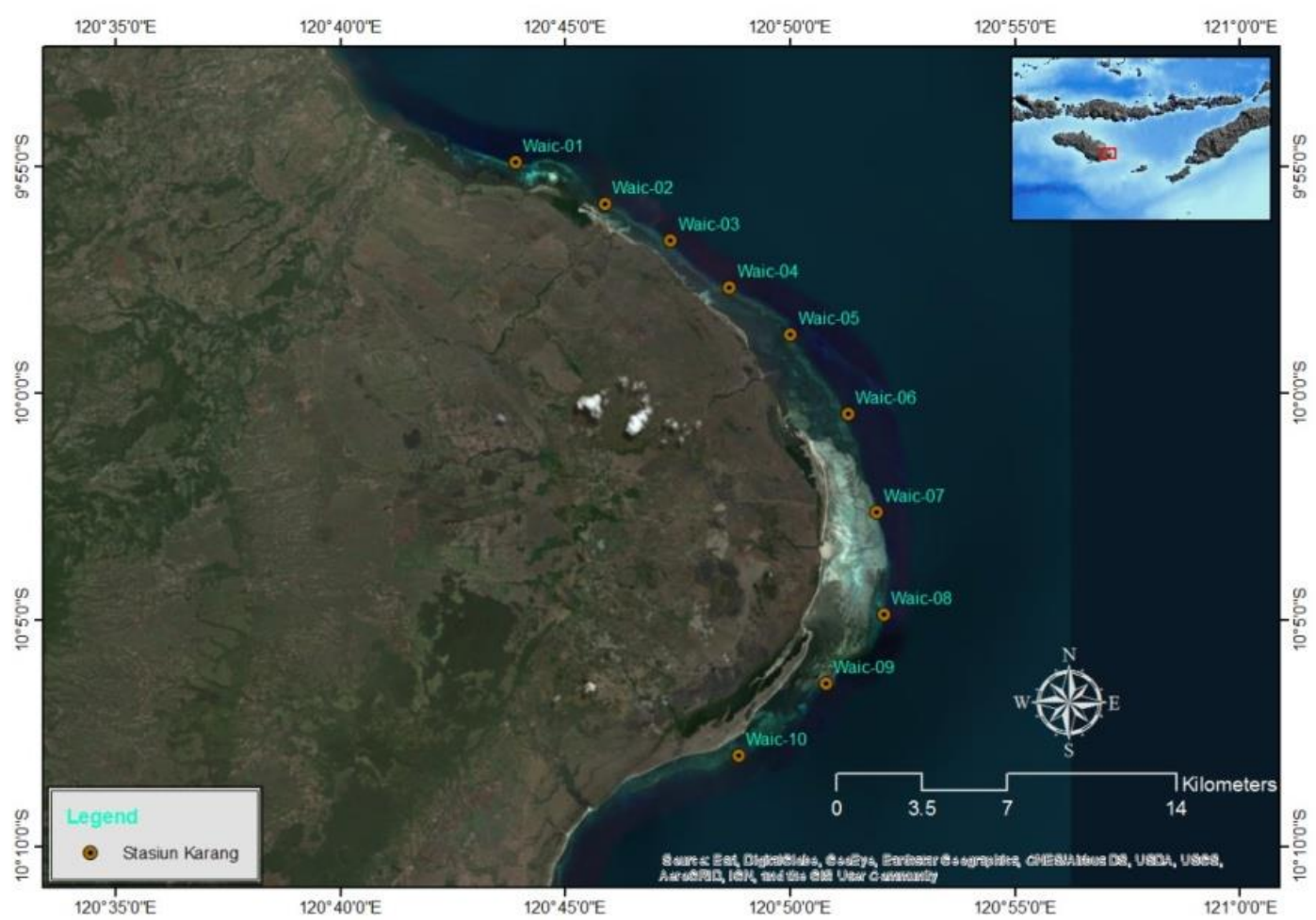

Gambar 1. Lokasi penelitian megabentos di perairan Kabupaten Sumba Timur.

Tabel 1. Stasiun penelitian megabentos di perairan Kabupaten Sumba Timur.

\begin{tabular}{cllcc}
\hline \multirow{2}{*}{ No. } & \multirow{2}{*}{ Stasiun } & \multirow{2}{*}{ Lokasi } & \multicolumn{2}{c}{ Posisi } \\
\cline { 4 - 5 } & & Dujur & Lintang \\
\hline 1 & WAIC01 & Desa Warajangga & 120,73142 & $-9,91492$ \\
2 & WAIC02 & Desa Tapil & 120,76454 & $-9,93052$ \\
3 & WAIC03 & Desa Tapil & 120,78898 & $-9,9437$ \\
4 & WAIC04 & Desa Panoho & 120,81082 & $-9,96103$ \\
5 & WAIC05 & Desa Panoho & 120,83349 & $-9,97855$ \\
6 & WAIC06 & Desa Nusa & 120,8548 & $-10,00778$ \\
7 & WAIC07 & Desa Nusa & 120,8652 & $-10,04394$ \\
8 & WAIC08 & Desa Warangbadi & 120,86792 & $-10,0814$ \\
9 & WAIC09 & Desa Mokaweni & 120,84653 & $-10,10682$ \\
10 & WAIC10 & Desa Mokaweni & 120,81413 & $-10,13334$ \\
\hline
\end{tabular}

\section{II.3. Analisa data}

Kepadatan individu megabentos dihitung dengan formula yang mengacu pada (Brower et al, 1998). Struktur komunitas moluska dihitung melalui pendekatan beberapa indeks ekologis, seperti indeks keanekaragaman jenis atau indeks Shannon $(\mathrm{H})$, indeks kemerataan jenis atau indeks Pielou (J), dan indeks dominansi Simpson (D) menggunakan primer 5 (Clarke and Warwick, 2001). 


\section{Hasil dan pembahasan}

\section{III.1. Deskripsi lokasi penelitian}

Pertumbuhan karang di perairan Kabupaten Sumba Timur merupakan tipe terumbu karang tepi (fringing reef). Pada umumnya karakter terumbu karang dengan rataan terumbu yang cukup panjang, dengan panjang antara 700-1 km diikuti dengan lereng terumbu yang landai $\left(15-25^{\circ}\right)$. Subtrat terumbu umumnya didominasi oleh DCA (dead coral with algae/karang mati ditutupi alga) dan pasir (Sand), namun pada beberapa lokasi, banyak ditemukan patahan karang (Rubble) yang disebabkan olah bekas penggunaan bom dan potas (potasium sianida) dalam menangkap ikan (destructive fishing).

Dari hasil pengamatan pada 10 stasiun ditemukan 204 jenis karang mewakili 42 marga dari 15 famili. Keanekaragaman jenis karang pada perairan ini cukup tinggi, dimana hampir $1 / 3$ jenis karang yang ada di Indonesia (590 jenis) dapat ditemukan di Perairan Sumba (Suharsono, 2008). Karang dari famili Acroporiidae cukup dominan pada perairan ini, ditemukan sebanyak 69 jenis. Penetrasi cahaya matahari dan sirkulasi air yang cukup baik merupakan faktor yang dapat mempercepat pertumbuhan karang jenis acropora. Jenis berikutnya yang ditemukan cukup banyak adalah dari famili Faviidae (53 jenis) dan Poritidae (15 jenis). Jenis karang dari kedua famili tersebut kebanyakan berupa karang masif dengan pertumbuhan yang lambat, namun cukup adaptif terhadap perubahan lingkungan terutama terhadap sedimentasi dan perubahan suhu. Pada saat lingkungan berubah mereka membuat lapisan mucus yang cukup tebal untuk melindungi mereka dari sedimen dan sebagai insulator panas. Meskipun memiliki tingkat pertumbuhan yang cukup cepat, karang rentan terhadap perubahan suhu ekstrim (suhu terlalu tinggi atau terlalu rendah). Pada perairan ini sering terjadi upwealing yang membawa suhu dingin dari dasar laut serta pada kasus tertentu, suhu permukaan laut dapat tinggi (bleaching alert).

Tutupan karang hidup secara keseluruhan pada setiap stasiun berkisar antara 5,2\%-31,93\%, dan jika merujuk pada kriteria Gomez dan Alcala (1978), yaitu jelek (0$24,9 \%)$ dan sedang $(25-49,9 \%)$, maka persentase tutupan karang hidup pada perairan Kabupaten Sumba Timur berada dalam kategori jelek-sedang. Ketegori bentik lain seperti fleshy seaweed, soft coral dan spons, memiliki persentase tutupan sekitar $60 \%$ lebih rendah dari pada tutupan karang, namun demikian jenis-jenis ini merupakan kompetitior bagi karang dalam mendapatkan ruang untuk tumbuh dan berkembang. Pada beberpa lokasi, seperti distasiun WAIC9 dan WAIC10 tutupan makroalga cukup tinggi. Kenaikan suhu perairan dan tingginya tingkat eutrofikasi mempercepat pertumbuhan fleshy seaweed, dan dapat menghambat laju recovery dari terumbu (DiazPulido et al, 2008). Secara umum kondisi perairan cukup jernih dengan jarak pandang horizontal mencapai $8-10 \mathrm{~m}$. Semua stasiun pengamatan berada pada lereng terumbu dengan kedalaman antara $6-9 \mathrm{~m}$.

\section{III.2. Kondisi fauna megabentos}

Hasil pengamatan megabentos di 10 stasiun ditemukan 7 jenis, mewakili tiga kelompok seperti kelompok ekinodermata yang terdiiri dari Diadema spp, Linkia Laevigata dan Holothurian, krustase hanya diwakili oleh Panulirus sp (lobster) dan 
moluska terdiri dari Drupella cornus, Tridacna spp. dan Trochus spp,Diadema spp. Drupella cornus dan Trochus spp. merupakan jenis yang paling umum, dan ditemukan hampir disemua stasiun (Tabel 2). Keragaman jenis megabentos dalam pengamatan ini relatif berimbang dengan hasil pengamatan dari perairan Pangkjene Kepulauan (Cappenberg, 2014), perairan Kepulauan Buton (Cappenberg et al, 2019), dan Arbi et al. (2020) di perairan Ternate, yang masing-masing menemukan 8 jenis. Kehadiran setiap kelompok megabentos pada masing-masing lokasi tidak lepas dari kondisi terumbu karang sebagai habitat hidup dari berbagai jenis biota tersebut. Ini mencerminkan bahwa ekosistem terumbu karang pada setiap lokasi masih berada dalam kondisi baik bagi kehadiran fauna megabentos. Terumbu karang merupakan salah satu ekosistem penting yang dapat memberi ruang bagi berbagai biota asosiasi untuk berlindung, mencari makan dan berkembang.

Tabel 2. Sebaran megabentos setiap stasiun di perairan Kabupaten Sumba Timur.

\begin{tabular}{|c|c|c|c|c|c|c|c|c|c|c|c|c|}
\hline \multirow[b]{2}{*}{ No. } & \multirow[b]{2}{*}{ Megabentos } & \multicolumn{10}{|c|}{ WAIC } & \multirow{2}{*}{$\begin{array}{c}\text { Frekuensi } \\
\text { Kehadiran } \\
(\%)\end{array}$} \\
\hline & & 1 & 2 & 3 & 4 & 5 & 6 & 7 & 8 & 9 & 10 & \\
\hline $\mathbf{I}$ & Ekinodermata & & & & & & & & & & & \\
\hline 1 & Diadema spp. & + & - & + & + & + & + & + & + & + & + & 90 \\
\hline 2 & Linkia laevigata & - & - & - & - & - & - & + & - & - & - & 10 \\
\hline 3 & Holothurian & - & + & - & + & - & - & - & - & - & + & 30 \\
\hline II & Krustasea & & & & & & & & & & & \\
\hline 4 & Lobster & - & + & - & - & - & - & - & - & - & - & 10 \\
\hline III & Moluska & & & & & & & & & & & \\
\hline 5 & Drupella cornus & + & + & + & + & + & + & + & + & + & - & 90 \\
\hline 6 & Tridacna spp. & + & - & + & + & - & - & + & + & + & + & 70 \\
\hline 7 & Trochus spp. & + & + & + & + & - & + & + & + & + & + & 90 \\
\hline \multicolumn{2}{|c|}{ Jumlah Individu } & 20 & 38 & 103 & 22 & 33 & 77 & 91 & 71 & 74 & 42 & \\
\hline \multicolumn{2}{|c|}{ Jumlah Jenis } & 4 & 4 & 4 & 5 & 2 & 3 & 5 & 4 & 4 & 4 & \\
\hline
\end{tabular}

Keragaman megabentos pada setiap stasiun cukup fluktuatif, dimana keragaman tertinggi terdapat di stasiun WAIC04 dan WAIC07 masing-masing 5 jenis, sedang yang terendah di stasiun WAIC05 (2 jenis). Kelimpahan individu megabentos tertinggi terdapat di stasiun WAIC03 (103 individu), diikuti stasiun WAIC07 (91 individu) dan Diadema spp. memiliki kontribusi terbesar terhadap tingginya nilai kelimpahan individu pada kedua stasiun tersebut, masing-masing sebanyak 53 individu dan 56 individu. Sedangkan stasiun WAI01 memiliki kelimpahan individu terendah (20 individu), dan Drupella cornus memiliki jumlah individu yang dominan dibandingkan jenis lainnya. Dari megabentos yang ditemukan, Diadema spp, Drupella cornus dan Trochus spp. memiliki sebaran yang luas, dan ditemukan hadir pada sembilan stasiun, dengan nilai persentase kehadiran sebesar 90\%, diikuti Tridacna spp. (70\%) atau hadir pada tujuh stasiun. Sedangkan Linkia laevigata dan Lobster memiliki nilai persentase kehadiran yang terendah (10\%), atau hanya ditemukan pada satu stasiun dari sepuluh stasiun pengamatan. Fluktuasi kehadiran jenis megabentos dapat dipengaruhi oleh tipe substrat sebagai habitat hidup, lingkungan perairan maupun faktor antropogenik (Dupont et al, 2010; Stark et al, 2014; Yuan et al, 2016 ). 
Berdasarkan jumlah individu fauna megabentos yang ditemukan, Diadema spp. memiliki jumlah total individu tertinggi, sebanyak 367 individu atau sebesar $64,27 \%$ dari total individu megabentos, diikuti oleh Drupella cornus, 148 individu (25,92\%). Sedangkan yang memiliki jumlah individu sangat rendah diwakili oleh Lobster ( 1 individu) atau hanya sebesar $0,18 \%$. Jenis lain seperti Linkia laevigata dicatat sebesar 0,35\% atau sebanyak 2 individu, teripang $0,70 \%$ (4 individu), kima 3,68\% (21 individu) dan Trochus spp. 4,90\% (28 individu). Rendahnya kelimpahan individu megabentos ekonomis penting, seperti Tridacna spp. (kima) Trochus spp (lola), teripang dan lobster yang ditemukan pada setiap stasiun, bukan disebabkan oleh kondisi terumbu karang yang tidak mendukung, namun karena ada aktivitas penangkapan yang berlebihan dari masyarakat setempat atau dari luar Pulau Sumba. Tingginya aktivitas penangkapan ini, akan mempengaruhi siklus hidup jenis-jenis tersebut, serta dapat menyebabkan menurunnya jumlah individu, yang mengakibatkan kepunahan (Gambar 2).

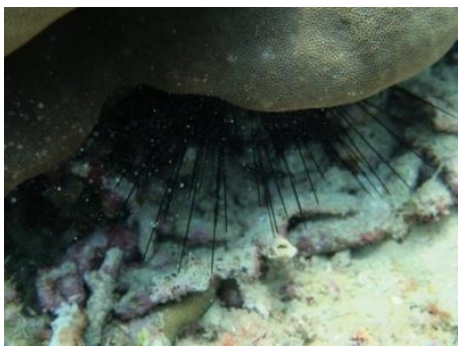

Diadema setosum

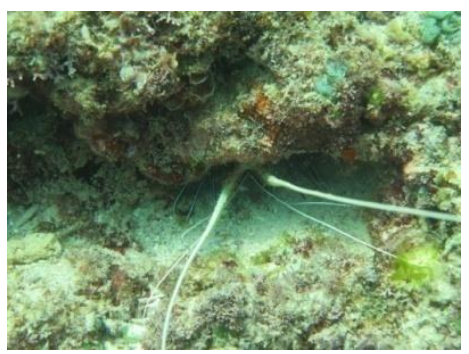

Panulirus sp. (Lobster)

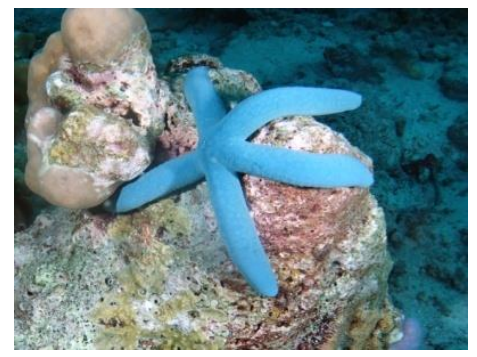

Linkia laevigata

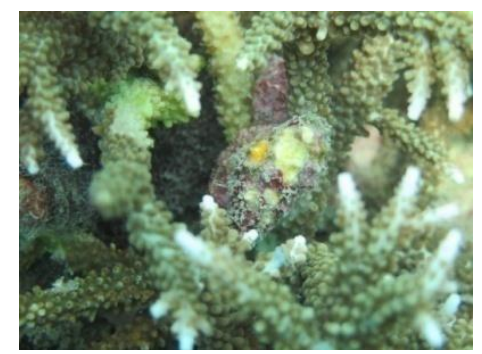

Drupella cornus

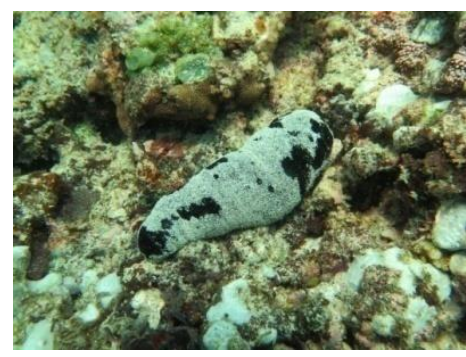

Holothurian (Teripang)

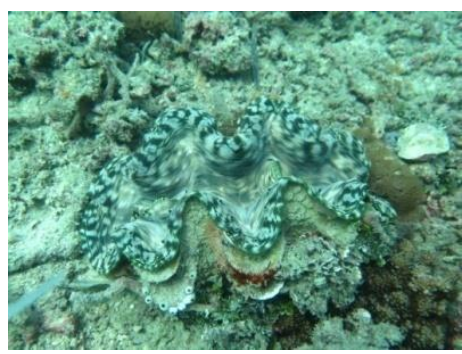

Tridacna squamosa (kima)

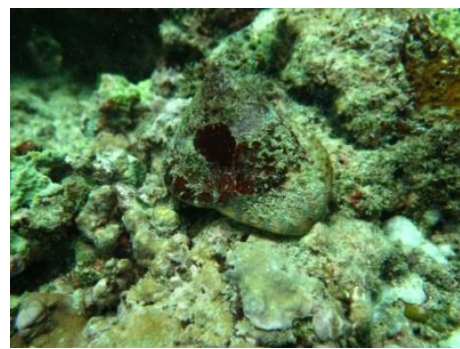

Trochus niloticus (lola)

Gambar 2. Jenis megabentos setiap stasiun di perairan, Kabupaten Sumba Timur.

\section{III.3. Kepadatan megabentos}

Distribusi nilai kepadatan individu megabentos pada setiap stasiun pengamatan cukup fluktuatif, berkisar antara 0,14-0,74 individu/m² (Gambar 3). Nilai kepadatan tertinggi terdapat pada stasiun WAIC3 sebesar 0,74 individu $/ \mathrm{m}^{2}$, dan diikuti stasiun 
WAIC7 $\left(0,65\right.$ individu/ $\left.\mathrm{m}^{2}\right)$. Tingginya nilai kepadatan pada stasiun WAIC3 sangat dipengaruhi oleh kehadiran kelompok ekinodermata $\left(0,38\right.$ individu $\left./ \mathrm{m}^{2}\right)$, dibandingkan kelompok moluska $\left(0,36\right.$ individu $\left./ \mathrm{m}^{2}\right)$. Kontribusi tertinggi dari kelompok ekinodermata pada stasiun tersebut hanya diwakili oleh kehadiran Diadema spp, $\left(0,38\right.$ individu $\left./ \mathrm{m}^{2}\right)$ dan Drupella cornus ( $\left(0,27\right.$ individu $\left./ \mathrm{m}^{2}\right)$ dari kelompok moluska. Sedangkan kontribusi terbesar terhadap nilai kepadatan individu di stasiun WAIC7 juga dipengaruhi oleh kehadiran Diadema spp. (0,40 individu $\left./ \mathrm{m}^{2}\right)$ dan Drupella cornus $\left(0,19\right.$ individu $\left./ \mathrm{m}^{2}\right)$. Sedangkan kepadatan individu terendah terdapat di stasiun WAIC01 $\left(0,1,4\right.$ individu $\left./ \mathrm{m}^{2}\right)$ yang terletak di pesisir timur Muara Jangga. Pada stasiun ini Drupella cornus $\left(0,08\right.$ ndividu $\left./ \mathrm{m}^{2}\right)$ memiliki kontribusiyang terbesar dibandingkan Diadema spp. (0,04 individu $\left./ \mathrm{m}^{2}\right)$. Secara umum, kontribusi kelompok ekinodermata cukup mempengaruhi tingginya nilai kepadatan megabentos hampir pada semua stasiun, dibandingkan kelompok moluska maupun krustase. (Tabel 3).

Kepadatan dan sebaran jenis dari kelompok ekinodermata dalam penelitian ini, hanya Diadema spp. yang memiliki nilai kepadatan yang tertinggi serta sebaran yang luas, dibandingkan Linckia laevigata dan holothurians. Kepadatan Diadema spp. dalam jumlah individu yang tinggi masing-masing ditemukan di stasiun WAIC3 $\left(0,38\right.$ individu/ $\left.\mathrm{m}^{2}\right)$, WAIC6 $\left(0,51\right.$ individu/ $\left.\mathrm{m}^{2}\right)$, WAIC7 $\left(0,40\right.$ individu $\left./ \mathrm{m}^{2}\right)$, WAIC8 $\left(0,43\right.$ individu $\left./ \mathrm{m}^{2}\right)$, WAIC9 $\left(0,45 \mathrm{individu} / \mathrm{m}^{2}\right)$ dan WAIN10 $\left(0,24\right.$ individu $\left./ \mathrm{m}^{2}\right)$. Tingginya nilai kepadatan individu Diadema spp. dipengaruhi oleh faktor substrat dan ketersediaan makanan. Jenis ini sangat menyukai tipe substrat yang didominasi oleh pasir serta perairan yang jernih (De Beer, 1990). Makanan utama Diadema spp. dan bintang laut lainnya berupa alga bentik (Collin and Arnesson, 1995), yang dalam pengamatan ini tersebar cukup merata pada hampir setiap stasiun. Pada kepadatan yang tinggi, Diadema mampu memakan semua organisme, sehingga akan menghalangi pertumbuhan karang. Kepadatan yang sangat rendah, alga akan mengambil alih daerah ini dan menghambat pertumbuhan karang. Grazing yang dilakukan D. setosum pada kepadatan yang sedang, mampu mengontrol pertumbuhan alga sehingga planula karang dapat menempel dan berkembang, dan secara tidak langsung membantu memelihara kelangsungan hidup terumbu karang (Sammarco et al, dalam Nybakken, 1992). Sedangkan rendahnya nilai kepadatan Diadema spp. di stasiun WAIC01 $(0,04$ individu/m²), diduga berhubungan dengan prefernsi makanannya (Aziz, 1994), serta kemampuan kompetisi yang rendah dalam menempati habitat (Kekenusa, 1993). Stasiun WAIC02 tidak ditemukan Diadema spp. Hal ini dipengaruhi oleh arus yang deras selama berlansungnya pengamatan, komponen penyusun terumbu karang yang didominasi oleh tutupan karang lunak $(58,6 \%)$, yang bukan merupakan substrat yang ideal bagi diadema. Tingginya nilai kepadatan Diadema spp. diikuti dengan rendah nilai tutupan karang pada hampir semua stasiun, dan umumnya berada dalam kategori rendah hingga sedang. Kehadiran Diadema dalam populasi yang tinggi mengindikasikan karang tidak sehat dan sebaliknya (Vimona, 2007).

Walaupun memiliki kemampuan hidup pada berbagai mikrohabitat perairan (Iken et al, 2010), kehadiran dan sebaran Linckia laevigata dalam pengamatan ini sangat terbatas, dan hanya ditemukan pada stasiun WAIC7 dengan kepadatan individu yang rendah $\left(0,01\right.$ individu $\left./ \mathrm{m}^{2}\right)$. Tinggi rendahnya kepadatan Linckia laevigata pada setiap stasiun mungkin berkaitan dengan ketersediaan makanan. sebagian besar bintang laut yang hidup di ekosistem terumbu karang seperti Linckia laevigata, L. multipora, Ophidiaster granifera, Echinaster luzonicus, Pentaceraster spp, dan Protoreaster spp, adalah merupakan pemakan detritus dan lapisan busuk dari biota sessil bentos (Aziz, 1996). Linckia laevigata juga jarang ditemukan pada kawasan dengan tingkat stress antropogenik dan pencemaran air yang tinggi (Ghafari et al, 2019), diman kehadiran dan perannya dalam membantu resiliensi karang secara langsung belum diketahui dengan pasti (Boss et al, 2008). 


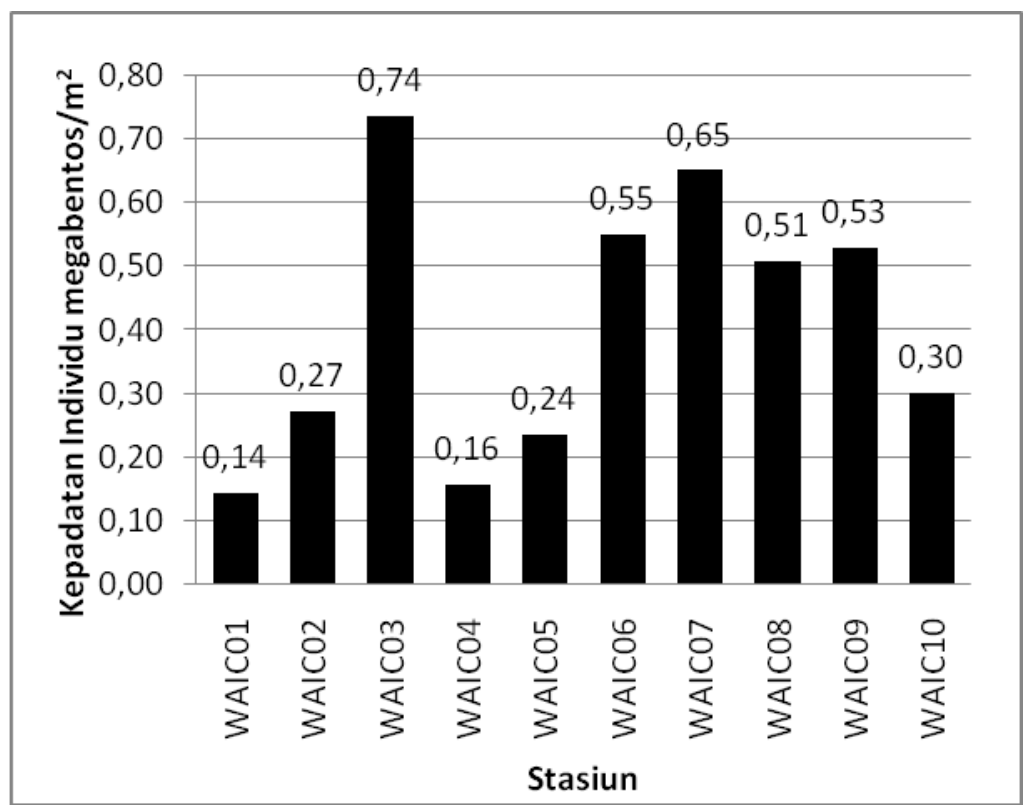

Gambar 3. Kepadatan megabentos pada setiap stasiun pengamatan

Kontribusi dari kepadatan individu Drupella cornus dalam pengamatan ini dicatat cukup fluktuatif dan relatif rendah, dimana nilai kepadatan tertinggi hanya terdapat di stasiun WAIC2 $\left(0,24 \mathrm{individ} / \mathrm{m}^{2}\right)$, WAIC3 $\left(0,37 \mathrm{individu} / \mathrm{m}^{2}\right)$ dan WAIC5 $\left(0,15 \mathrm{individu} / \mathrm{m}^{2}\right)$. Rendahnya kepadatan individu $D$. cornus diduga dipengaruhi oleh ketersediaan jenis-jenis karang seperti dari genus Acropora, montipora, pocillopara dan seriotopora sebagai target makanannya yang tersebar tidak merata pada setiap stasiun. Ketersediaan jenis-jenis karang tersebut sebagai target makanan yang tidak tersebar secara merata pada setiap stasiun, turut mempengaruhi kehadiran Drupella cornus. Kondisi ini memperkuat pernyataan Jimenez et al. (2012) bahwa ada tidaknya Drupella pada terumbu karang, dipengaruhi oleh ketersediaan makanan. Penempelan Drupella pada karang dipengaruhi oleh adaptasi dalam pemilihan makanan, seperti pada karang bercabang dari genus Acropora, Montipora, Pocillopra dan Seriotopora (Turner, 1994; Hoeksema et al, 2013). Namun Drupella juga dapat beradaptasi mendapatkan makanan lainnya bila target makanan utamanya tidak ada atau mati. Cumming and Mc Corry (1998), dalam penelitian di perairan Hong Kong melaporkan, Drupella cornus ditemukan memangsa karang Platygyra karena pada daerah tersebut tidak ada jenis karang dari genus Acropora dan Pocillopora, sedangkan di Teluk Eilat, Israel (Shafir, 2008), melaporkan bahwa genus Drupella menempel pada Turbinaria, Pavona, Milepora dan Porites setelah karang bercabang mati.

Kepadatan individu D. cornus yang ditemukan dalam pengamatan ini umumnya rendah $\left(0,01-0,27\right.$ individu $\left./ \mathrm{m}^{2}\right)$. Kisaran nilai ini tidak jauh berbeda dengan yang ditemukan oleh Cappenberg (2014), di perairan Pangkajene $\left(0,12-0,21\right.$ individu/ $\left.\mathrm{m}^{2}\right)$. Kondisi ini menunjukkan bahwa kehadiran Drupella pada terumbu karang di perairan Indonesia tidak mengganggu pertumbuhan karang secara nyata, jika dibandingkan dengan hasil pengamatan Ayling and Ayling (1987) di rataan terumbu karang Ningalon, Australia Barat dengan kepadatan individu sebesar 15,7 individu/ $\mathrm{m}^{2}$, mampu merusak terumbu karang hingga $85 \%$ dalam waktu 10 tahun. Black and Johnson (1994) di daerah yang sama, melaporkan bahwa akibat aktivitas makan Drupella menyebabkan pemutihan karang mencapai $22 \%$ dari luasan tutupan karang. Kondisi ini 
menunjukan bahwa dengan kepadatan Drupella cornus $<2$ individu $/ \mathrm{m}^{2}$, tidak akan menyebabkan kerusakaran yang serius pada terumbu karang yang berada pada setiap stasiun pengamatan di perairan Kabupaten Sumba Timur.

Drupella tidak memangsa semua jenis karang, tetapi memilih mangsanya karena berbagai alasan yang kompleks seperti bentuk pertumbuhan dari koloni karang, kemudahan untuk mendapatkan jaringan karang hidup, produksi lendir dari karang, nilai nutrisi serta kemampuan mempertahankan diri dengan sel penyengat "nematosit" (Gabbi, 1999). Barco et al. (2010) menyatakan meskipun tidak ada hubungan yang signifikan, namun kehadiran Drupella memiliki asosiasi yang kuat dengan terumbu karang sebagai hewan parasit. Beberapa penelitian mengatakan bahwa kehadiran Drupella pada suatu koloni karang erat kaitannya dengan kondisi kesehatan terumbu karang, dan umumnya cenderung menempel pada koloni karang yang tidak sehat. Kondisi ini menunjukkan bahwa kehadiran dan kepadatan Drupella cornus yang rendah, tidak memiliki dampak yang signifikan terhadap kerusakan karang di perairan Kabupaten Sumba Timur.

Fauna megabentos yang memiliki nilai ekonomis penting seperti Holothurians (teripang), Panulirus sp. (lobster) Tridacna spp. (kima) dan Trochus spp. (lola) yang ditemukan dalam penelitian ini, hanya Tridacna spp. dan Trochus spp. memiliki nilai kepadatan yang tinggi. Sedangkan Holothurian dan Panulirus sp, memiliki nilai kepadatan yang rendah, dengan persebaran yang terbatas. Umumnya kisara nilai kepadatan dari keempat jenis megabentos tersebut berkisar antara 0,01 - 0,06 individu $/ \mathrm{m}^{2}$ (Tabel 3). Dari keempat jenis-jenis megabentos ekonomis penting, lola memiliki nilai total kepadatan tertinggi $\left(0,19\right.$ individu $\left./ \mathrm{m}^{2}\right)$, diikuti kima $(0,16$ individu $/ \mathrm{m}^{2}$ ). Sedangkan Panulirus sp, memiliki nilai total kepadatan inidividu yang tertendah $\left(0,01\right.$ individu $\left./ \mathrm{m}^{2}\right)$ dan hanya ditemukan pada stasiun WAIC2. Kondisi ini mungkin berhubungan dengan sifat hidupnya yang nokturnal, yang hanya aktif di malam hari untuk mencari makan. Substrat sebagai habitat hidup pada hampir semua stasiun, memiliki kriteria yang cukup baik dan sesuai bagi keberadaan jenis-jenis tersebut. Umumnya, tersusun dari batu karang masive, berlubang, berongga dan banyak celah, karang mati ditumbuhi alge dan diselingi pasir. Poutiers (1998) menyatakan lola dan kima biasanya hidup pada terumbu karang, perairan dangkal yang jernih hingga kedalaman 20m. Lobster dan teripang juga mendiami kawasan terumbu karang dengan tipe substrat yang beragam, dimana masing-masing menempati mikrobaitatnya. Artinya terumbu karang merupakan tempat asosiasi organisme yang kompleks dan mempunyai sejumlah tipe habitat yang berbeda-beda dan semuanya berada dalam satu sistem yang sama (Nybakken, 1992).

Menurut penduduk lokal (komunikasi pribadi), berkurangnya jenis-jenis megabentos ekonomis dari lokasi pengamatan, disebabkan oleh aktifitas penangkap oleh penduduk setempat maupun nelayan yang datang dari luar pulau. Berdasarkan cara hidupnya yang menetap, bergerak dengan lambat dan meliang/bersembunyi pada celah/celah karang membuat jenis-jenis ini dapat dengan mudah ditangkap dan biasanya dilakukan pada malam hari saat air surut. Karena memiliki nilai jual tinggi dan menjadi komoditi perikanan yang diperdagangkan bebas di pasar lokal maupun internasional, membuat jenis-jenis ini menjadi target buruan masyarakat pesisi/nelayan. teripang menjadi target buruan nelayan/masyarakat pesisir. 
Tabel 3. Nilai kepadatan individu megabentos setiap stasiun

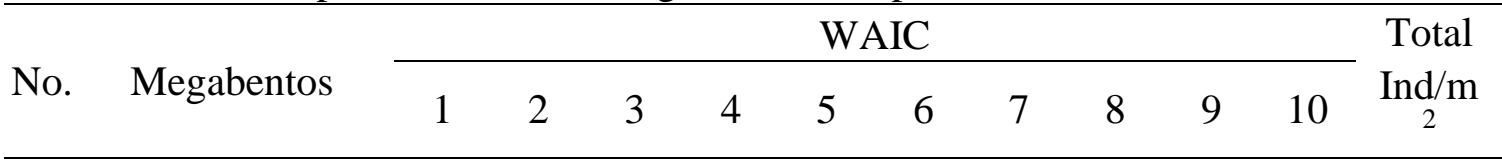

\begin{tabular}{|c|c|c|c|c|c|c|c|c|c|c|c|c|}
\hline I & Ekinodermata & & & & & & & & & & & \multirow[b]{2}{*}{2,62} \\
\hline 1 & Diadema spp. & $\begin{array}{c}0,0 \\
4\end{array}$ & $\begin{array}{c}0,0 \\
0\end{array}$ & $\begin{array}{c}0,3 \\
8\end{array}$ & $\begin{array}{c}0,0 \\
9\end{array}$ & $\begin{array}{c}0,0 \\
9\end{array}$ & $\begin{array}{c}0,5 \\
1\end{array}$ & $\begin{array}{c}0,4 \\
0\end{array}$ & $\begin{array}{c}0,4 \\
3\end{array}$ & $\begin{array}{c}0,4 \\
5\end{array}$ & $\begin{array}{c}0,2 \\
4\end{array}$ & \\
\hline 2 & $\begin{array}{l}\text { Linckia } \\
\text { laevigata }\end{array}$ & $\begin{array}{c}0,0 \\
0\end{array}$ & $\begin{array}{c}0,0 \\
0\end{array}$ & $\begin{array}{c}0,0 \\
0\end{array}$ & $\begin{array}{c}0,0 \\
0\end{array}$ & $\begin{array}{c}0,0 \\
0\end{array}$ & $\begin{array}{c}0,0 \\
0\end{array}$ & $\begin{array}{c}0,0 \\
1\end{array}$ & $\begin{array}{c}0,0 \\
0\end{array}$ & $\begin{array}{c}0,0 \\
0\end{array}$ & $\begin{array}{c}0,0 \\
0\end{array}$ & 0,01 \\
\hline 3 & Holothurian & $\begin{array}{c}0,0 \\
0\end{array}$ & $\begin{array}{c}0,0 \\
1\end{array}$ & $\begin{array}{c}0,0 \\
0\end{array}$ & $\begin{array}{c}0,0 \\
1\end{array}$ & $\begin{array}{c}0,0 \\
0\end{array}$ & $\begin{array}{c}0,0 \\
0\end{array}$ & $\begin{array}{c}0,0 \\
0\end{array}$ & $\begin{array}{c}0,0 \\
0\end{array}$ & $\begin{array}{c}0,0 \\
0\end{array}$ & $\begin{array}{c}0,0 \\
1\end{array}$ & 0,03 \\
\hline II & Krustase & & & & & & & & & & & \multirow[b]{2}{*}{0,01} \\
\hline 4 & Panulirus sp. & $\begin{array}{c}0,0 \\
0\end{array}$ & $\begin{array}{c}0,0 \\
1\end{array}$ & $\begin{array}{c}0,0 \\
0\end{array}$ & $\begin{array}{c}0,0 \\
0\end{array}$ & $\begin{array}{c}0,0 \\
0\end{array}$ & $\begin{array}{c}0,0 \\
0\end{array}$ & $\begin{array}{c}0,0 \\
0\end{array}$ & $\begin{array}{c}0,0 \\
0\end{array}$ & $\begin{array}{c}0,0 \\
0\end{array}$ & $\begin{array}{c}0,0 \\
0\end{array}$ & \\
\hline III & Moluska & & & & & & & & & & & \\
\hline 5 & Drupella cornus & $\begin{array}{c}0,0 \\
8\end{array}$ & $\begin{array}{c}0,2 \\
4\end{array}$ & $\begin{array}{c}0,2 \\
7\end{array}$ & $\begin{array}{c}0,0 \\
4\end{array}$ & $\begin{array}{c}0,1 \\
5\end{array}$ & $\begin{array}{c}0,0 \\
2\end{array}$ & $\begin{array}{c}0,1 \\
9\end{array}$ & $\begin{array}{c}0,0 \\
4\end{array}$ & $\begin{array}{c}0,0 \\
1\end{array}$ & $\begin{array}{c}0,0 \\
0\end{array}$ & 1,06 \\
\hline 6 & Tridacna spp. & $\begin{array}{c}0,0 \\
1\end{array}$ & $\begin{array}{c}0,0 \\
0\end{array}$ & $\begin{array}{c}0,0 \\
2\end{array}$ & $\begin{array}{c}0,0 \\
1\end{array}$ & $\begin{array}{c}0,0 \\
0\end{array}$ & $\begin{array}{c}0,0 \\
1\end{array}$ & $\begin{array}{c}0,0 \\
2\end{array}$ & $\begin{array}{c}0,0 \\
1\end{array}$ & $\begin{array}{c}0,0 \\
5\end{array}$ & $\begin{array}{c}0,0 \\
1\end{array}$ & 0,16 \\
\hline 7 & Trochus spp. & $\begin{array}{c}0,0 \\
1 \\
\end{array}$ & $\begin{array}{c}0,0 \\
1 \\
\end{array}$ & $\begin{array}{c}0,0 \\
6 \\
\end{array}$ & $\begin{array}{c}0,0 \\
1 \\
\end{array}$ & $\begin{array}{c}0,0 \\
0 \\
\end{array}$ & $\begin{array}{c}0,0 \\
1 \\
\end{array}$ & $\begin{array}{c}0,0 \\
2 \\
\end{array}$ & $\begin{array}{c}0,0 \\
1 \\
\end{array}$ & $\begin{array}{c}0,0 \\
1 \\
\end{array}$ & $\begin{array}{c}0,0 \\
4 \\
\end{array}$ & 0,19 \\
\hline & $\begin{array}{l}\text { Total } \\
\text { Individu } / \mathrm{m}^{2}\end{array}$ & $\begin{array}{c}0,1 \\
4\end{array}$ & $\begin{array}{c}0,2 \\
7\end{array}$ & $\begin{array}{c}0,7 \\
4\end{array}$ & $\begin{array}{c}0,1 \\
6\end{array}$ & $\begin{array}{c}0,2 \\
4\end{array}$ & $\begin{array}{c}0,5 \\
6\end{array}$ & $\begin{array}{c}0,6 \\
5\end{array}$ & $\begin{array}{c}0,5 \\
0\end{array}$ & $\begin{array}{c}0,5 \\
3\end{array}$ & $\begin{array}{c}0,3 \\
0\end{array}$ & 4,08 \\
\hline
\end{tabular}

\section{III.4. Keragaman megabentos}

Hasil analisis beberapa indeks ekologis terhadap komunitas megabentos di pesisir pantai Kabupaten Sumba Timur, diperoleh nilai yang beragam pada masing-masing stasiun (Tabel 4). Nilai indeks keanekaragaman jenis (H') berkisar antara 0,43-1,14. Nilai tertinggi terdapat pada stasiun WAIC1 $(1,14)$ dan diikuti stasiun WAIC4 $(1,11)$, sedangka nilai terendah terdapat pada stasiun WAIC6 (0.43). Daget (1976) menyatakan, jika indeks keanekaragaman suatu komunitas kurang dari 1,0, keanekaragaman jenisnya rendah, sedangkan jika nilainya berkisar antara 1,0 - 2,0, keanekaragaman jenisnya sedang, dan bila nilainya lebih dari 2,0, dikategorikan memiliki keanekaragaman jenis yang tinggi, serta dapat menjadi salah satu parameter untuk mengetahui kondisi suatu komunitas (Pirzan et el, 2008). Berdasarkan kriteria Deget (1976), keanekaragaman jenis megabentos di pesisir pantai Kabupaten Sumba Timur umumnya tergolong rendah hingga sedang. Rendahnya nilai indeks keanekaragaman jenis pada beberapa stasiun pengamatan, disebabkan oleh distribusi individu yang tidak proporsional pada setiap jenis megabentos, namun ada terjadi dominasi individu pada jenis tertentu.

Nilai indeks kemerataan jenis ( $J$ ') berkisar antara 0,31-0,95, dimana nilai kemerataan tertinggi berada di stasiun WAIC5 $(0,95)$, diikuti stasiun WAIC1 $(0,82)$ dan terendah di stasiun WAIC6 (0.31). Fluktuasi nilai ini menggambarkan sebaran jenis megabentos yang tidak merata atau tidak stabil dalam ekosistem terumbu karang. Jika nilai indeks kemerataan jenis kurang dari 0,5 maka komunitas dalam kondisi tertekan, jika nilainya berkisar antara 0,5 - 0,75 maka komunitas berada dalam kondisi labil, dan jika nilainya berkisar anatar 0,75 - 1,0 maka komunitas berada dalam kondisi stabil (Daget, 1976). Berdasarkan nilai indeks kemerataan jenis, dapat dikatakan bahwa komunitas megabentos di stasiun penelitian berada dalam kondisi tertekan hingga stabil. 
Tabel 4. Indeks ekologi megabentos di Kabupaten Sumba Timur.

\begin{tabular}{lccccc}
\hline Stasiun & $\begin{array}{c}\text { Jumlah } \\
\text { Jenis } \\
(\mathrm{S})\end{array}$ & $\begin{array}{c}\text { Jumlah } \\
\text { individu } \\
(\mathrm{N})\end{array}$ & $\begin{array}{c}\text { Indeks } \\
\text { Keanekaragaman } \\
\left(\mathrm{H}^{\prime}\right)\end{array}$ & $\begin{array}{c}\text { Indeks } \\
\text { Kemerataan } \\
\left(\mathrm{J}^{\prime}\right)\end{array}$ & $\begin{array}{c}\text { Indeks } \\
\text { Dominasi } \\
(\mathrm{D})\end{array}$ \\
\hline WAIC1 & 4 & 20 & 1,14 & 0,82 & 0,35 \\
WAIC2 & 4 & 38 & 0,45 & 0,32 & 0,80 \\
WAIC3 & 4 & 103 & 1,03 & 0,74 & 0,40 \\
WAIC4 & 5 & 21 & 1,18 & 0,74 & 0,39 \\
WAIC5 & 2 & 33 & 0,66 & 0,95 & 0,52 \\
WAIC6 & 4 & 80 & 0,35 & 0,25 & 0,81 \\
WAIC7 & 5 & 91 & 0,97 & 0,60 & 0,46 \\
WAIC8 & 4 & 70 & 0,55 & 0,39 & 0,74 \\
WAIC9 & 4 & 74 & 0,56 & 0,40 & 0,73 \\
WAIC10 & 3 & 41 & 0,66 & 0,47 & 0,70 \\
\hline
\end{tabular}

Komunitas dikatakan stabil, bila mempunyai nilai indeks kemerataan jenis mendekati angka 1, dan sebaliknya tidak stabil atau tertekan jika nilai kemerataannya mendekati 0 (Tabel 4). Odum (1971) menyatakan sebaran dikatakan merata apabila nilai kemerataan jenisnya berkisar antara 0,6-0,8. Berdasarkan Hal tersebut menunjukkan bahwa beberapa stasiun memiliki sebaran jenis yang merata (WAIC 1, WAIC3, WAIC4, WAIC5 dan WAIC7). Komunitas megabentos yang stabil pada lima stasiun tersebut menunjukkan rendahnya nilai dominasi jenis (Tabel 4). Nilai ini mengindikasikan bahwa tidak ada kompetisi yang berarti diantara fauna megabentos dalam mendapatkan makanan dan ruang untuk hidup. Sedangkan stasiun lainnya memiliki sebaran jenis yang kurang merata (WAIC2,WAIC6, WAIC8, WAIC9 dan WAIC10). Indeks kemerataan jenis erat kaitannya dengan nilai dominasi individu yang ada pada masing-masing stasiun. Artinya fauna megabentos yang ditemukan pada setiap stasiun, memiliki proporsi individu yang tidak berimbang.

Nilai indeks dominasi berkisar antara 0,35-0,81. Nilai dominasi (D) terendah terdapat pada stasiun-stasiun yang memiliki nilai kemerataan jenis yang tinggi. Sebaliknya dominansi jenis yang tinggi ditemukan pada stasiun dengan nilai kemerataan jenis yang rendah (Tabel 4). Berdasarkan kriteria Odum (1991) yang menyatakan jika nilai indeks dominasi (D) kurang dari 0,5 maka dominasi dalam komunitas rendah. Artinya semua jenis megabentos yang hadir pada stasiun-stasiun tersebut berada dalam jumlah individu yang berimbang, sebaliknya tingginya nilai dominasi jenis diikuti dengan rendahnya nilai kemerataan jenis. Tingginya nilai dominasi ini disebabkan oleh adanya pemusatan individu dari Diadema spp. dan Drupella cornus pada stasiun-stasiun tersebut. Tingginya nilai dominasi menunjukkan ada tekanan ekologis yang tinggi (Hartati dan Awwalludin, 2007).

Secara umum, kehadiran megabentos bentik pada pengamatan ini cukup fluktuatif, dan memiliki nilai rata-rata indeks keanekaragaman $\left(\mathrm{H}^{\prime}=0,74\right)$ dan kemerataan $\left(\mathrm{J}^{\prime}=0,57\right)$ yang rendah serta nilai dominasi jenis yang cukup tinggi $(\mathrm{D}=$ 0,59). Rendahnya nilai-nilai indeks ekologi ini ( $H^{\prime}$ dan J'), merupakan respons dari adanya kompetisi untuk mendapatkan makan dan ruang serta perubahan pada lingkungan habitat, musim, kondisi hidrologis ataupun proses reproduksi (Odum, 1971). Beberapa jenis cenderung muncul dalam agregasi, dan distribusinya dapat dipengaruhi oleh hubungan biotik atau karakteristik substrat seperti ukuran butiran, kandungan 
organik (Conand, 1989; Conand and Chardy, 1985; Uthicke and Karez, 1999; Tuya et al, 2006; Shiell and Knott 2010; Slater and Jeffs 2010; Dissanyake and Stefansson 2012), maupun habitat sebagai tempat berlindung (Shiell and Knott, 2008). Bila tekanan pada lingkungan terus meningkat dalam waktu yang lama, dapat mempengaruhi keberadaan megabentos, terutama yang bersifat menetap (sessile), ataupun yang memiliki pergerakan yang sangat terbatas. Kondisi ini memperlihatkan bahwa selain berperan penting dalam siklus nutrien dan produsen sekunder dalam perairan, megabentos juga berperan penting dalam menyokong rantai makanan dalam ekosistem sebagai makanan untuk ikan demersal maupun mamalia laut (Kröncke and Reiss, 2010; Tabatabaien and Amiri, 2011; Sahidin dan Wardiatno, 2016), dan dapat menjadi salah satu bioindikator dalam menilai kondisi suatu perairan (Dean, 2008; Shokat et al, 2010; Sharma et al, 2018).

\section{Kesimpulan}

Fauna megabentos yang ditemukan dalam pengamatan di perairan Kabupaten Sumba Timur cukup beragaman ( 7 jenis dari total 8 jenis target pengamatan). Diadema spp. memiliki jumlah individu yang sangat dominan, yang dicatat sebesar 64,27\% dari total individu yang ditemukan dan memiliki kontribusi yang sangat besar terhadap tinggi rendah nilai kepadatan individu megabentos. Megabenthos ekonomis penting seperti lobster, teripang, kima dan lola masih dapat ditemukan pada beberapa stasiun dengan nilai kepadatan individu yang rendah. Secara umum keanekaragaman fauna megabentos pada perairan Kabupaten Sumba Timur berada dalam kondisi rendah hingga sedang.

\section{Ucapan Terima Kasih}

Penulis mengucapkan terima kasih kepada Pusat Penelitian Oseanografi-Lembaga Ilmu Pengetahuan Indonesia (P2O- LIPI) atas pendanaan penelitian ini di bawah skema Reef Health Monitoring P2O - LIPI Program COREMAP-CTI Tahun Anggaran 2018.

\section{Daftar Pustaka}

Abbott R.T. and P. Dance. 1990. Compendium of Seashell. Australia. Crawford House Press. 411 pp.

Arbi, U.Y, A. Harahap and H.A.W. Cappenberg, 2020. Fluktuasi kondisi megabentos di perairan Ternate MalukuUtara. Jurnal Kelautan Trpis. Vol. 23 (1): 57 - 72.

Arthur M.R.H. 1972. Geographycal ecology pattern in the distribution species. Harper and Row. Publish. New York. 260pp.

Ayling A.M. and A.L. Ayling. 1987. Ningaloo Marine Park: preliminary fish density assessment and habitat survey, with information on coral damage due to Drupella grazing, Report to the Department of Conservation and Land Management, Western Australia.

Aziz A. 1994. Tingkah laku bulu babi di padang lamun. Oseana. P30-LIPI. Jakarta. 14(4): $35-43$.

Aziz A. 1996. Makan dan cara makan berbagai jenis bintang laut. Oseana. P30-LIPI. Jakarta, 21(3): $13-22$. 
Barco A, M. Claremont, D.G. Reid, R. Hobart, P.. Bouchet, S.T. Williams, C. Cruaud, A, Couloux and M. Oliverio. 2010. A molecular phylogenetic framework for the Muricidae, a diverse family of carnivorous gastropods. Mol Phylogenet Evol. 56:1025-1039.

Black R. and M. S. Johnson. 1994. Growth Rates in Outbreak Population of The Corallivorous Gastropoda Drupella Cornus (Roding 1798) at Ningaloo Reef, western Australia. Coral reff 13:145 - 150.

Boss, A.R, Alipoyo, J.C, Cardona, L.T, Gumanao, G.S, and Salac, F.N, 2008. Population structure of common IndoPacific sea stars in the Davao Gulf, Philippines. UPVJournal of Natural Science, 13, 11-24.

Bozec, Y, L. Alvarez-Filip, and P. J. Mumby. (2015). The dynamics of architectural complexity on coral reefs under climate change. Global Change Biol. 21, 223235.

Brower, J.E, J.H. Zar, and C.N. von Ende. 1998. Field and Laboratory Methods for General Ecology. Fourth. USA: Mc.Graw-Hill Companies Inc.

Cappenberg H.A.W. 2014. Struktur komunitas megabentos di Perairan Pangkajene Kepulauan, Kabupaten Pangkep, Sulawesi Selatan. Zoo Indonesia 2014. 23(2):57-67.

Cappenberg H.A.W. dan R.T. Mahulette. 2019. Sebaran dan kepadatan megabentos di perairan Pulau Buton, Sulawesi Tenggara. BAWAL. II (2): 79 - 93.

Clark A.M. and F.W.E. Rowe. 1971. Monograph of shallow-water Indo-west Pasific Echino- derms. Trustees of the British Muse- um (Nat. Hist.). London : 238 pp.

Collin P.L. and C. Arnesson 1995. Tropical Pasific Invertebrates. Coral Reef Prees, California: 209 pp.

Conand C. 1989. Les holothuries aspidochirotes du lagon de Nouvelle-Calédonie: Biologie, écologie et exploitation. Etudes et thèses ORSTOM, Paris

Conand C. and P. Chardy. 1985. Are the aspidochirote holothurians of the New Caledonian lagoon good indicators of the reefal features? In: Proc 5th Int Coral Reef Congr, Vol 5. Antenne Museum-EPHE, Moorea, Tahiti. 291-296.

Cumming R.L. and D. McCorry. 1998. Corallivorous gastropods in Hong Kong. Coral Reef 17:78.

Daget, J. 1976. Les Modeles Mathematique En Ecologie. Masson Coll. Ecoll. 8: 172 pp.

Dance P. 1976. The collector's encyclopedia of shell. New Jersey. Cartwell Book Inc. $288 \mathrm{pp}$.

Dean H.K. (2008). The use of polychaetes (Annelida) as indicator species of marine pollution: a review. Int J Trop Biol 56 (4): 11-38.

De Beer M. 1990. Distribution patterns of regular sea urchins (Echinodermata: Echinnoides) cross the Spermonde shelf, SW Sulawesi (Indonesia). In De Ridder, Dubois, Lahaye and Jangoux (Eds.). Proceedings of the second European conference on echinoderms Brussels,Belgium, 18 - 21 September 1989 (p.165-169). Leiden: National Museum of National History.

Dharma, B. 2005. Resent and fossil Indonesia shell. Conchbook, Hackenheim. Germany. 424 pp.

Diaz-Pulido, G. and L.J. McCook. 2008. Macroalgae (Seaweed) in China, the State of Great Barrier Reef On-line. Great Barrier Reef Marine Park Authority, Townsville. 
Dissanyake D.C.T. and G. Stefansson. 2012. Habitat preference of sea cucumbers: Holothuria atra and Holothuria edulis in the coastal waters of Sri Lanka. J Mar Biol Assoc UK 92:581-593.

Dupont, S, O. Ortega-Martinez, dan M. Thorndyke. 2010. Impact of near-future ocean acidification on echinoderms. Ecotoxicology, 19(3): 449-462.

Fabricius, K. E, G. De'ath, S. Noonan, and S. Uthicke. 2013. Ecological effects of ocean acidification and habitat complexity on reef-associated macroinvertebrate communities. P. Roy. Soc. B-Biol. Sci 281, 20132479.

Gabbi G. 1999. Shells: Guide to the jewels of the sea. Turin: Periplus. 168 pp.

Ghafari, M.I.A, G. Hadiprayitno, M.L. Ilhamdi, dan N.M. Satyawan. 2019. Struktur komunitas Echinodermata di kawasan intertidal Gili Meno, Lombok Utara. ALKAUNIYAH:Jurnal Biologi, 12(2): 181-188.

Giyanto, A.E. Manuputty, M. Abrar, R.M. Siringoringo, S.R. Suharti, dan K. Wibowo. K, . 2014. Panduan Monitoring Kesehatan Terumbu Karang. Terumbu Karang, Ikan Karang, Megabenthos dan Penulisan Laporan. (Suharsono, dan O.K. Sumadhiharga, Eds.). Jakarta: COREMAP CTI LIPI.

Gomez, E.D. and A.C. Alcala. 1978. Stastus of Philiphina coral reef. Project, Int. Symp.Biogeogr. Evol. S. Hem. Auckland New Zealand, 17 - 20 July 1978. 2: 663-669.

Ham, Y. 2018. El Niño events set to intensify. Nature 564, 192-193.

Hartati, S. T. dan Awwaluddin. 2007. Struktur komunitas makrozoobentos di perairan Teluk Jakarta. Perikanan Indonesia. 13 (2):105-124.

Hoegh-Guldberg, O, P.J. Mumby, A.J. Hooten, R.S. Steneck, P. Greenfield, and E.Gomez, 2007. Coral reefs under rapid climate change and ocean acidification. Science 318, 1737-1742.

Hoeksema B.W, C. Scott, and J.D. True. 2013. Dietary shift in corallivorous drupella snails following a major bleaching event at Koh Tao Gulf of Thailand. Coral Reef : $1-6$.

Hughes, T.P, J.T. Kerry, A.H. Baird, S.R. Connolly, A. Dietzel, and C.M. Eakin. 2018. Global warming transforms coral reef assemblages. Nature 556,492-526.

Iken K, Konar, B, Benedetti-Cecchi, L, Cruz-Motta, J.J, Knowlton, A, Pohle, G, Mead A, Iloslavich P, Wong M. and Trott T. 2010. Large-scale spatial distribution patterns of echinoderms in nearshore rocky habitats. PLOS ONE. 5(11):e13845.

Jimenez H, P. Dumas, D. Ponton, J. Ferraris 2012. Predicting Invertebrate Assemblage Composition from Harvesting Pressure and Environmental Characteristics on Tropical Reef Flats. Coral Reefs 31:89-100.

Kekenusa J.S. (1993). Pola penyebaran, keanekaragaman dan asosiasi antara species teripang di pesisir pantai barat Pulau Nain, Sulawesi Utara. Jurnal Fakultas Perikanan UNSRAT, 11(4): 11-17.

Kröncke, I, and H. Reiss. 2010. Influence of macrofauna longterm natural variability on benthic indices used in ecological quality assessment. Marine Pollution Bulletin, 60(1), 58-68. DOI: 10.1016/j.marpolbul.2009.09.001.

Manuputty A.E.W, Giyanto, Winardi, Suharti, A.R. and Djuwaria. 2006. Manual Monitoring kesehatan karang (Reef health monitoring). Jakarta: LIPI.

Nybakken J.W. 1992. Biologi laut, suatu pendekatan ekologi. PT. Gramedia Pustaka Utama. Jakarta. 496 hal.

Odum, E.P. 1971. Fundamental of ecology. W. E. Sunders, Philadelphia : $574 \mathrm{hlm}$. 
Pirzan A.M. dan P.R. Pong-Masak. 2008. Hubungan Keragaman Fitoplankton dengan Kualitas Air di Pulau Bauluang, kabupaten Takalar, Sulawesi Selatan. Biodiversitas. Vol. 9 (3) : 217-221.

Poutiers J. 1998. The Living Marine Resources of The Western Central Pasific. Vol.1: Seaweeds, corals, bivalves and gastropods. FAO of The United Nation. 686 pp.

Przeslawski, R, S. Ahyong, M. Byrne, G. Worheides, and P. Hutchings. 2008. Beyond corals and fish: the effects of climate change on noncoral benthic invertebrates of tropical reefs. Global Change Biol. 14, 2773-2795.

Sahidin A, dan Y Wardiatno. 2016. Spatial distribution of Polychaete at Tangerang coastal water, Banten Province. J Fish Mar 6 (2): 83-94.

Shafir, S, O. Gur, and B. Rinkevich. 2008. A Drupella cornus outbreak in the northern Gulf of Eilat and changes in coral prey. Coral Reefs, 27(2): 379-379.

Sharif S. and B. Rinkevich. 2008. A Drupella cornus outbreaks in the northen Gulf of Eilat and changes in coral prey. Coral Reef 27: 379.

Sharma, S.D, R.R. Behera, U. Mohapatra, C.R. Panda, and L. Nayak. 2018. Effect of estuarine effluents on benthic faunal communities in relations to tidal dynamics of Dhamra estuary. World Journal of Pharmaceutical and Life Sciences, 4(2), 127-134.

Shiell G.R. and B. Knott. 2008. Diurnal observations of sheltering behaviour in the coral reef sea cucumber Holothuria whitmaei. Fish Res 91: 112-117.

Shiell G.R. and B. Knott. 2010. Aggregations and temporal changes in the activity and bioturbation contribution of the sea cucumber Holothuria whitmaei (Echinodermata: Holothuroidea). Mar Ecol Prog Ser 415: 127-139.

Shokat P, S.M.B. Nabavi, A. Savari, and P. Kochanian. 2010. Ecological quality of Bahrekan coast, by using biotic indices and benthic communities. Transit. Waters Bull 4 (1): 25-34

Slater M.J. and A.G. Jeffs. 2010. Do benthic sediment characteristics explain the distribution of juveniles of the deposit-feeding sea cucumber Australostichopus mollis? J Sea Res 64: 241-249.

Stark, J.S, Kim, S.L, and Oliver, J.S, 2014. Anthropogenic disturbance and biodiversity of marine benthic communities in Antartica: A regional comparison. PloS One, 9(6): $1-24$.

Suharsono. 2008. Jenis-Jenis Karang di Indonesia. LIPI Press, Jakarta. 344 hlm.

Tabatabaie T. and F. Amiri. 2011. Evaluation of the impact of industrial sewage pollution on marine benthic communities. Journal of Water Supply: Res Technol-AQUA 60 (6): 364-374.

Turner S.J. 1994. The biology and population outbreaks of the coalliovorous gastropods drupella on Indo-Pacific Reefs. Oceanogr. Mar. Biol. Ann. Rev. 32: 461 - 530.

Tuya F, J.C. Hernández and S. Clement. 2006. Is there a link between type of habitat and the patterns of abundance of holothurians in shallow rocky reefs? Hydrobiologia 571:191-199.

Uthicke S. and R. Karez. 1999. Sediment patch selectivity in tropical sea cucumbers (Holothuroidea: Aspidochirotida) analysed with multiple choice experiments. J Exp Mar Biol Ecol 236: 69-87.

Vimono I. B. 2007. Sekilas mengenai landak laut. Oseana XXXII(3): 15 - 21.

Warwick, R.M. and Clarke, K.R. 2001. Change in marinre communities: an approach to statistical analysis and interpretation. Plymouth, Natural Environmental Research Council : Bourne Press. 
Wilson B. 1993. Australian Marine Shells. Vol. I. Western Australia: Odyssey Publishing. 406 pp.

Yuan, X, S. Shao, X. Yang, D. Yang, Q. Xu, and H. Zong. 2016. Bioenergetic tradeoffs in the sea cucumber Apostichopus japonicus (Echinodermata: Holothuroidea) in response to $\mathrm{CO} 2$-driven ocean acidification. Enveronmental Science and Pollution Research, 23(9): 8453-8461. 